\title{
DURABILITY OF NEW RECYCLED GRANITE QUARRY DUST-BEARING CEMENTS
}

\author{
G. Medina ${ }^{1 *}$, I.F. Sáez del Bosque ${ }^{2}$, M. Frías ${ }^{3}$, M.I. Sánchez de Rojas ${ }^{3}$, C. Medina ${ }^{2^{* *}}$ \\ 1. Departamento Ingenierías Mecánica, Informática y Aeroespacial, Escuela de Ingenierías Industrial e \\ Informática, Universidad de León, Campus de Vegazana, s/n, 24071 - León, Spain \\ 2. Departamento de Construcción, Escuela Politécnica de Cáceres - Grado de Ingeniería Civil, \\ Universidad de Extremadura, Unidad Asociada UEX-CSIC, Instituto de Investigación de Desarrollo \\ Territorial Sostenible (INTERRA), 10003 - Cáceres, Spain \\ 3. Departamento de Cementos y Reciclado de Materiales, Instituto de Ciencias de la Construcción \\ Eduardo Torroja (IETCC-CSIC), 28033 - Madrid, Spain \\ Corresponding author: *gmedinaia@gmail.com /
}

\section{Abstract}

Imperative to the design of new cements that bear different types of waste as additions is a parallel study of the mechanical strength and durability of the new materials to ensure their performance will be satisfactory throughout their service life. This study explored the effect of adding $10 \%$ or $20 \%$ granite quarry dust to cement on properties such as transport (total and capillary water absorption and electrical resistivity), dimensional stability (drying shrinkage and expansion), the alkali-silica reaction, heat of hydration and colour. No alkali-silica reaction was observed in the new materials and expansion and contraction were less intense than in conventional cement. The water absorption and capillary absorption coefficients rose less in the additioned cements than the replacement ratio, whilst their higher resistivity values afforded greater corrosion protection than found in the reference. The inclusion of this waste also prompted a rise in lightness and a decline in peak heat of hydration. The multivariate analysis of variance (MANOVA) conducted showed that the factors time and replacement ratio affected the properties significantly, whereas the combined effect of the two was statistically significant or otherwise depending on the property analysed. The findings showed that the partial replacement of cement with quarry dust is not detrimental to product durability and the recycled material qualifies as a strength class 42.5, type II/A. Adittionally, the binders bearing $20 \%$ granite quarry dust meet the requirements to qualify as low heat cements (CEM II/A LH).

Keywords: transport, dimensional stability, heat of hydration, granite quarry dust, recycled cements

\section{INTRODUCTION}


Of the 4.6 billion tonnes of cement produced by the cement industry in $2016,47 \%$ was used in residential construction, $32 \%$ in commercial construction and $21 \%$ in civil works [1]. Those figures are indicative of the vast amounts of natural resources consumed by the industry and of its enormous potential to reduce that consumption by reusing waste, either generated in construction per se or in other industries.

In recent years the cement industry has made a huge effort to develop alternative inputs, known as supplementary cementitious materials (SCMs), in the design of new cements. Their use would lower energy consumption and the GHG emissions intrinsic to cement manufacture. Much research has been conducted the world over to analyse the viability of valorising waste, primarily from the fired clay, agroforestry, steelmaking and ornamental stone industries.

Granite quarrying is estimated to account for over $30 \%$ of the total volume of ornamental stone waste. The vast amounts (125 Mt in 2012) [2] involved are presently deposited in land fills, with the concomitant damage to the environment and risk to human health, both causes for concern in modern societies.

With a view to solving these problems, in recent years researchers have tested the viability of valorising (coarse, fine and dust) quarry waste as a raw material in new eco-efficient materials. The literature identifies three major applications for valorising industrial waste: i) fine or coarse aggregates for sustainable concretes [2-5] or mortars [6]; ii) partial cement replacements in the design of new concretes (up to $30 \%$ ) [7, 8] or cements (up to $10 \%$ ) [9]; and iii) other uses, such as geopolymers [10] or roof tiles [11]. Much of the scant research conducted worldwide to date on the valorisation of such waste in cement has focused primarily on mechanical strength or chloride penetration-related durability.

That has left a large scientific-technical gap in the understanding of other properties associated with material durability, such as: i) indirect indicators of transport intensity (water absorption, capillarity and electrical resistivity) [12]; ii) volume change resulting from drying shrinkage or early-age swelling that may induce micro- or macrocracking, compromising service life [13]; iii) the alkali-silica reaction due to the simultaneous presence of moisture, reactive silica and cement-borne alkalis, forming silica gel and subsequently map-like cracking [14]; and iv) the heat released during hydration, possibly generating steep thermal gradients that may prompt cracking, a major concern in structures requiring large volumes of concrete such as dams [15]. 
This study consequently sought to further knowledge of the effect of partially (10\% or $20 \%$ ) replacing cement with granite quarry dust on the physical and mechanical characteristics, durability and colour of type II/A cements. The variables studied included $28 \mathrm{~d}$ mortar mechanical performance and pore size distribution, along with transport (water absorption, capillarity and resistivity), drying shrinkage and swelling, the alkali-silica reactivity of the new pozzolan and the calorimetric properties and colour of these new binary cements. A multivariate analysis of variance (MANOVA) was conducted to determine the effect of age and replacement ratio on mortar performance and bivariate correlations between the variables studied were established.

\section{MATERIALS AND EXPERIMENTAL}

\subsection{Materials}

The granite quarry dust (AF) analysed was furnished by an ornamental stone quarry at Quintana de la Serena in the Spanish province of Badajoz (region of Extremadura). The waste generated by the quarry is presently carried directly to uncontrolled spoil banks, a practice with obvious environmental implications (Figure 1). Representative samples collected by random selection from three heights on the on-site stockpile were subsequently homogenised in the laboratory. After selection, the waste was dried and characterised chemically, physically and mineralogically.

Figure 1. Stockpiled granite quarry dust

The X-ray fluorescence analysis of this dust performed in an earlier study [16] showed that it was acidic $\left(\mathrm{SiO}_{2}+\mathrm{Al}_{2} \mathrm{O}_{3}+\mathrm{Fe}_{2} \mathrm{O}_{3}>85.0\right.$ wt\%) with $1.5 \mathrm{wt} \%$ to $4.0 \mathrm{wt} \%$ of $\mathrm{Na}_{2} \mathrm{O}$ and $\mathrm{K}_{2} \mathrm{O}$, as well as other minority oxides. Tectosilicates, phyllosilicates and hematites prevailed in Its mineralogical composition [16].

CEN-standardised, European standard EN 196-1 [17]-compliant sand with a particle size ranging from $2.0 \mathrm{~mm}$ to $0.078 \mathrm{~mm}$ was used.

A non-reactive limestone $\left(\approx 97 \% \mathrm{CaCO}_{3}\right)$ sand with a particle size of $4.0 \mathrm{~mm}$ to $0.063 \mathrm{~mm}$ was also used to analyse the alkali-silica reactivity of the granite quarry dust included as a pozzolan in the design of type II/A cements.

The EN 197-1 [18]-compliant CEM I 42.5 R ordinary portland cement (OPC) used was furnished by Lafarge, a Spanish cement manufacturer sited in the province of Toledo. 


\subsection{Blends}

The blended cements were prepared in a high-speed powder mixer to guarantee homogeneity. Blend proportions were computed by weight, with OPC/AF ratios of 100/0 (OPC), $90 / 10(\mathrm{OPC}+10 \% \mathrm{AF})$ and $80 / 20(\mathrm{OPC}+20 \% \mathrm{AF})$. These replacement ratios were adopted on the grounds of the percentages allowed for type II/A (6\% to $20 \%$ ) cements in European standard EN 197-1 [18].

The pore size distribution of the cements shown in Figure 2 was obtained by measuring $\mathrm{N}_{2}$ absorption isotherms on a Micrometrics ASAP 2000 analyser. All the cements were observed to have pore diameters ranging from $0.7 \mathrm{~nm}$ to $190 \mathrm{~nm}$. The OPC had a small shoulder at $2.0 \mathrm{~nm}$ and cements $\mathrm{OPC}+10 \% \mathrm{AF}$ and $\mathrm{OPC}+20 \% \mathrm{AF}$ had two each, at $1.6 \mathrm{~nm}$ and $2.0 \mathrm{~nm}$. The new shoulder at $1.6 \mathrm{~nm}$ would be attributed to the addition, as observed by Medina et al. [19].

Figure 2. Pore size distribution for cements $\mathrm{OPC}, \mathrm{OPC}+10 \% \mathrm{AF}$ and $\mathrm{OPC}+20 \% \mathrm{AF}$ Including the addition induced a minor decline in the BET specific surface of the cement, from the $1.37 \mathrm{~m}^{2} / \mathrm{g}$ in OPC to $1.34 \mathrm{~m}^{2} / \mathrm{g}$ in OPC+10\%AF and $1.32 \mathrm{~m}^{2} / \mathrm{g}$ in OPC $+20 \% A F$. This property would not, then, affect the performance of the new binary cements designed.

\subsection{Standard methods and mortar manufacture}

Table 1 lists the physical and mechanical properties and durability variables assessed for the new cements, as well as the methodology and specimen sizes used.

Table 1. Physical, mechanical and durability variables studied With the exception of the mortars used to analyse the possible alkali-silica reactivity of the new addition, all the mortars were standardised and prepared with a sand/cement ratio of 3 . The mortars used to test for the alkali-silica reaction, in contrast, had a sand/cement ratio of 2.26.

The mortars were prepared as specified in standard EN 196-1 [17].

Mortar colour was measured on powdered blends of cement and waste pressed into pellets to a density of $1.8 \mathrm{~g} / \mathrm{cm}^{3}$.

\subsection{Characterisation}

The instrumental techniques used to characterise the microstructure of the new cements and assess the heat released, heat of hydration and colour are described below. The pore size distribution of the $28 \mathrm{~d}$ mortars was determined on a Micromeritics Autopore IV 9500 mercury 
porosimeter able to operate at pressures of up to $33000 \mathrm{psi}(227.5 \mathrm{MPa})$ and measure pore diameters of $0.006-175 \mu \mathrm{m}$. This trial was conducted to ASTM standard D 4404 [20].

The microstructural damage induced by immersing the mortars in an $\mathrm{NaOH}$ solution for the alkali-silicate reactivity test was assessed with backscattering electron microscopy (BSE). Samples removed from the centre of the specimens were embedded in epoxy resin, epoxycoated, precision-sawed and carefully polished for study under a Hitachi S4800 scanning electron microscope coupled to a Bruker Nano XFlash 5030 silicon drift EDX detector.

The colour parameters were quantified on a Minolta CM-2500d portable spectrophotometer for positioning on the $L^{*} a^{*} b^{*}$ colour space (where $L^{*}$ is lightness and $a^{*}$ and $b^{*}$ the chromaticity coordinates) defined by the International Commission on Illumination (CIE) (Commission internationale de l'éclairage) in 1976 [21].

\subsection{Statistical analysis}

A MANOVA was conducted to assess the findings recorded for the mortars studied (OPC, $\mathrm{OPC}+10 \% \mathrm{AF}$ and $\mathrm{OPC}+20 \% \mathrm{AF}$ ), testing for the significance of the effect of age and replacement ratio, as well as the interaction between them, on macroscopic properties.

As the significance level defined in the statistical study was $\alpha=0.05$, factors with a lower $p$-value were determined to have a significant effect on the results obtained.

Pearson's coefficient was calculated to determine the strength of the bivariate linear relationships at $5 \%$ significance.

IBM SPSS Statistics 2.0 software, version 22, was used for the statistical analyses.

\section{RESULTS AND DISCUSSION}

\subsection{Bulk density}

The bulk density for the $28 \mathrm{~d}$ mortars is given in Table 2 . The data showed that including granite quarry dust lowered density relative to the reference by $0.08 \%$ with a $10 \%$, and by $0.16 \%$ with a $20 \%$ replacement ratio.

Table 2. Bulk density and mechanical performance in $28 \mathrm{~d}$ mortars

That finding was directly related to the effect of including the new addition on total porosity (see Table 3), which was linearly related to density further to the equation $y=-3.96 x+2334$ $\left(R^{2}=0.997\right)$, where $y$ is density and $x$ total porosity. The trend observed was consistent with 
earlier observations by researchers working with other types of waste, such as marble [22] and fired-clay blocks [23], as cement additions.

\subsection{Mechanical strength}

According to the data in Table 2, all the mortars studied exhibited $28 \mathrm{~d}$ compressive strength $\geq 42.5 \mathrm{MPa}(42.5 \mathrm{~N} / 42.5 \mathrm{R})$. Strength was lower in the materials bearing granite quarry dust, due primarily to two factors: i) increase in total porosity (see Table 3), with a larger volume of macropores, the fraction with the heaviest impact on mechanical strength [24]; and ii) the quarry dust's slow pozzolanic reaction rate $[16,19]$. That behaviour was also observed in previous studies when additions of a similar nature, namely ornamental stone such as marble [25] or slate [26] or others characterised by low reactivity such as copper slag [27], fly ash [28, 29] or silico-manganese slag [30], were added to cement. The strength values nonetheless showed that the new cements met the strength requirements laid down in the standards in place for strength class $42.5 \mathrm{MPa}[18]$.

The flexural strength data followed a similar pattern, with strength declining with rising granite quarry dust content.

\subsection{Total porosity and pore size distribution}

The total porosity and pore size distribution in the $28 \mathrm{~d}$ mortars and the linear equations relating these properties to the replacement ratio are listed in Table 3 . Total porosity was observed to be $3.35 \%$ higher in mortar $\mathrm{OPC}+10 \% \mathrm{AF}$ and $7.28 \%$ higher in mortar OPC+20\%AF than in the reference OPC.

Table 3. Total porosity and pore size distribution in $28 \mathrm{~d}$ mortars

Both additioned mortars were observed to have slightly higher macropore $(\phi>0.05 \mu \mathrm{m})$ and capillary pore $(0.007<\varphi<0.05 \mu \mathrm{m})$ fractions than the reference. In the latter fraction, the smallest capillary pores were the ones most heavily impacted, due to waste pozzolanicity.

These findings were consistent with earlier reports on the behaviour of industrial waste (fly ash [31], bagasse ash [32], bottom ash [33] and waste water sludge [34]) included as pozzolanic additions in new cement design.

\subsection{Electrical resistivity}

The electrical conductivity of the mortars analysed is plotted versus time in Figure 3 . Three regions can be distinguished on the curves: i) a first, up to $4 \mathrm{~d}$ and particularly on the first day 
when the mortars bearing granite quarry dust had a higher conductivity than the OPC; ii) a second, up to $16 \mathrm{~d}$ when conductivity was similar in the three mortars, and iii) a third, where the conductivity pattern was $\mathrm{OPC}+20 \% \mathrm{AF}<\mathrm{OPC}+10 \% \mathrm{AF}<\mathrm{OPC}$. Those findings were consistent with earlier studies on mortars containing fly ash [35] or sugar cane bagasse ash [36], which like granite quarry dust are characterised by low early age pozzolanicity.

Figure 3. Electrical conductivity versus time Moreover, resistivity, defined as the inverse of conductivity and which rose with age and replacement ratio, was observed to be $9.1 \%$ higher in $\mathrm{OPC}+10 \% \mathrm{AF}$ and $17.2 \%$ higher in $\mathrm{OPC}+20 \% \mathrm{AF}$ than in OPC. Similar patterns were observed by other authors studying this property in cements with additions such as andesite [37], fluid catalytic cracking catalyst residue (FCC) [38], rice husk [39], silica fume [40] and blast furnace slag [40].

As noted by Baroghel et al. [41], this improved behaviour is associated with the additionprompted decline in alkalis and $\mathrm{OH}^{-}$ions in the pore system, which reduces ion mobility in the pore solution. The outcome, higher resistivity as observed here, would counter the decline in that property induced by a more intensely connected pore system [41, 42].

Figure 3 also revealed a potential correlation between conductivity and time. That relationship was defined in an earlier study by Andrade et al. [43] as $y=y_{o} \cdot(t)^{q}$, where $y$ is the value of conductivity at a given age; $y_{o}$ is conductivity at the first given age; $t$ is time; and $q$ is the ageing factor that represents hydration progress. The fourth parameter, $q$, is essential to establishing the durability models proposed by Andrade and D'Andrea [44] and laid down in Spain's Code on Structural Concrete, EHE-08 [45] and Model Code 2010 [46]. The $q$ values were observed to be higher for the new type II/A cements than for type I conventional cement, as observed by Andrade and D'Andrea [43] for cement types II/V and II/P. Moreover, these values for ageing factor are within the 0.2-0.8 range showed for this parameter in Model Code 2010 [47].

The inference drawn from the values for $28 \mathrm{~d}$ electrical resistivity was that the inclusion of granite quarry dust had no adverse effect on that durability indicator, for all the materials exhibited values ranging from $100 \Omega^{*} m$ to $200 \Omega^{*} m$, i.e., defined by a number of authors $[41,48]$ as moderate steel corrosion risk (M).

\subsection{Drying shrinkage}


The drying shrinkage measured in the mortars dried for $40 \mathrm{~d}$ in air at $20{ }^{\circ} \mathrm{C}$ and $60 \% \mathrm{RH}$ is shown in Figure 4. Whilst contraction was similar in all three mortars in the first $48 \mathrm{~h}$, the presence of granite quarry dust subsequently mitigated shrinkage, which was $13.5 \%$ lower in $\mathrm{OPC}+10 \% \mathrm{AF}$ and $19.1 \%$ lower in $\mathrm{OPC}+20 \% \mathrm{AF}$ than in the reference OPC.

Those findings were also consistent with the results of earlier studies on additions such as blast furnace slag [49], fly ash [50] and rock wool waste [51].

Figure 4. Drying shrinkage in mortars dried in air for $40 \mathrm{~d}$ at $20^{\circ} \mathrm{C}$ and $60 \% \mathrm{RH}$ The better drying shrinkage behaviour observed in the additioned mortars was attributed to a number of factors: i) the linear relationship between heat of hydration and drying shrinkage (see 3.11), observed by Hu et al. [52] and Zhan et al. [49]; ii) the effect of fineness on shrinkage [49], with greater fineness $(\mathrm{OPC}>\mathrm{OPC}+10 \% \mathrm{AF}>\mathrm{OPC}+20 \% \mathrm{AF})$ translating into greater shrinkage; iii) the higher free water content [34] in OPC than in the additioned mortars, which have a higher water demand [19]; and iv) the pore structure, which conditions the capillary pressure generated in the pore system as per the Kelvin-Laplace equation. With respect to iv), a critical pore size of $0.10 \mu \mathrm{m}$ was found for this property in the present study (see Table 3), which also identified a linear relationship between total shrinkage and volume of pores under $0.10 \mu \mathrm{m}$. The equation fitted to that curve was $y=0.22 x-0.49\left(R^{2}=0.966\right)$, where $y$ is drying shrinkage and $x$ the volume of pores under $0.10 \mu \mathrm{m}$. The same effect was observed by Kwon et al. [53], who noted that mortars with lower total porosity, a smaller volume of pores $>0.10 \mu \mathrm{m}$ and a greater volume of pores $<01.0 \mu \mathrm{m}$ exhibited greater drying shrinkage.

Figure 4 also shows the log regressions for the relationship between drying shrinkage and time, along with the correlation coefficients (all over 0.95).

\subsection{Expansion}

The expansion observed in the mortars after immersion in water for $40 \mathrm{~d}$ at a temperature of $20^{\circ} \mathrm{C}$ is shown in Figure 5. The increase in volume found for all the mortars tested was attributed to water absorption by C-S-H gels, which tend to sponge when in contact with fluids $[54,55]$. The lower C-S-H content in the additioned than in the OPC mortar [19] would explain why OPC $+10 \%$ AF exhibited $20 \%$ less expansion and OPC+20\%AF $40 \%$ less than OPC.

Figure 5. Expansion in mortars immersed in water at $20^{\circ} \mathrm{C}$ 
The figure shows that $25 \%$ to $33 \%$ of the expansion took place within the first $24 \mathrm{~h}$, which is consistent with reports by Martauz et al. [56]. Figure 5 also shows the log regressions for the relationship between expansion and time and the respective correlation coefficients, all over 0.93 .

\subsection{Alkali-silica reaction}

Mortar expansion after immersion in a $1 \mathrm{~N} \mathrm{NaOH}$ solution for $28 \mathrm{~d}$ at $80^{\circ} \mathrm{C}$ is shown in Figure 6. Less expansion was observed in mortars OPC $+10 \% \mathrm{AF}$ and $\mathrm{OPC}+20 \% \mathrm{AF}$ than in OPC and the $14 d$ and $28 d$ values were lower than the $0.10 \%$ ceiling stipulated in the national legislation [57] and the $0.20 \%$ recommended in international standards [58]. These data confirmed that the granite quarry dust added to the cements exhibited no alkali-silica reactivity.

Figure 6. Expansion in mortars immersed in a $1 \mathrm{~N} \mathrm{NaOH}$ solution at $80^{\circ} \mathrm{C}$

The decline in expansion with higher proportions of the addition was directly associated with the lower alkali content in the pore solution and lower $\mathrm{Ca}(\mathrm{OH})_{2}$ content in $\mathrm{OPC}+20 \% \mathrm{AF}$, an effect generally accepted by the research community, as noted by Kawabata and Yamada [59].

The present findings were also consistent with observations reported by Al-Fadala et al. [60] and Saha and Sarker [61], according to which the inclusion of volcanic or fly ash failed to induce the alkali-silica reaction. Those authors also recorded lesser expansion in the additioned mortars.

The BSE micrographs recorded at the end of the test for the alkali-silica reaction (Figure 7) showed that all the cements exhibited a similar appearance, with no indication of the formation of expansive silica gels or therefore of cracking.

Figure 7. BSE micrographs (500x) of $28 \mathrm{~d}$ mortars tested for the alkali-silica reaction: a) OPC; b)

$$
\mathrm{OPC}+10 \% \mathrm{AF} ; \mathrm{c}) \mathrm{OPC}+20 \% \mathrm{AF}
$$

\subsection{Total and capillary absorption}

The water absorption and capillary absorption coefficient values for $28 \mathrm{~d}$ mortars are given in Table 4. Mortar OPC+10\%AF absorbed $7.1 \%$ more water, and mortar OPC+20\%AF $14.8 \%$ more water than the reference OPC.

Those findings were consistent with earlier reports for additions with pozzolanicity similar to that of the granite dust studied here, such as copper slag [27], fly ash [28], ground granulated blast furnace slag [28] and concrete waste ash [62]. 
Table 4. Total water absorption, capillary absorption coefficient and peak temperature in the mortars studied

The data recorded were directly related to the linear relationship between this property and both density (see 3.1, the higher the density the lower the absorption values [63]) and porosity and pore size distribution (Figure 8) [64]. As Figure 8 shows, total porosity and the size of the macropore fraction were more closely correlated to total absorption than capillary pore volume.

Figure 8. Water absorption and capillary absorption coefficient versus porosity: a) OPC; b)

$$
\mathrm{OPC}+10 \% \mathrm{AF} ; \mathrm{c}) \mathrm{OPC}+20 \% \mathrm{AF}
$$

Further to the data in Table 4, the capillary absorption coefficient was slightly higher in the mortars bearing granite waste cement than in the reference OPC, by $10.3 \%$ in $\mathrm{OPC}+10 \% \mathrm{AF}$ and $13.7 \%$ in $\mathrm{OPC}+20 \% \mathrm{AF}$.

Those observations were the direct result of the increase in both total porosity and the volume of capillary pores in the mortars bearing granite quarry dust (see Figure 9$)(\Phi<0.05 \mu \mathrm{m})$. The effect is visible in Figure 8, which shows the linear relationship between the increase in porosity (total porosity and macro- and capillary pore volume) and the capillary absorption coefficient in the mortars studied. The capillary fraction was observed to have a greater impact than total porosity on capillary absorption, a finding reported previously by Martys and Ferraris [65].

Rises in capillary absorption as a direct effect of the increase in capillary pore volume were also recorded by researchers studying the impact of additions such as biomass bottom ash [66], calcined marl [67], fly ash [68] and granulated blast furnace slag [69] on that property.

The capillary absorption curves plotted in Figure 9 proved to be similar for all three mortars studied (OPC, OPC+10\%AF and OPC+20\%AF), while also showing that the inclusion of the addition induced a rise in water absorbed and lengthened the time taken to reach saturation due to the higher volume of capillary pores. The curves were characterised by rapid early age (up to $24 \mathrm{~h}$ ) absorption, which subsequently slowed due to rehydration and hydration of the paste components, developments that modified their microstructure and with it pore connectivity [70, 71]. In the final, saturated stage sample weight remained constant, during which period the pores filled with air as a result of diffusion [72].

Figure 9. Capillary absorption curves in mortars

\subsection{Heat of hydration}


The peak temperature of the heat released by the mortars analysed is given in Table 4 . The data showed lower maximum heat in the mortars containing granite quarry dust than in the reference: $5.5 \%$ lower in OPC+10\%AF and $19.3 \%$ lower in OPC+20\%AF. Similar behaviour has been reported for other pozzolanic materials included in new cements at similar replacement ratios, such as paper mill sludge [73], fly ash [74], fired clay-based sanitary ware [15] and milled ash [29].

Heat of hydration in the mortars analysed is plotted against time (up to $120 \mathrm{~h}=5 \mathrm{~d}$ ) in Figure 10.

Figure 10. Total heat of hydration in mortars versus time Heat of hydration rose rapidly in the first $15 \mathrm{~h}$, and then more slowly, peaking at $30 \mathrm{~h}$ and remaining essentially flat through the end of the test.

Heat of hydration was also observed to decline as the replacement ratio rose. The mortar containing $10 \%$ granite quarry dust released $6.4 \%$ less heat and the $20 \%$ additioned mortar $20 \%$ less than the control OPC. That behaviour can be explained by the linear relationship between heat of hydration and the replacement ratio observed by Medina et al. [15]. The relationship observed here fit the equation $y=-2.79 x+317\left(R^{2}=0.974\right)$, where $y$ is heat of hydration and $x$ the replacement ratio.

The decline observed was consistent with a trend reported by authors $[74,75]$ studying the early age effect of low pozzolanicity mineral additions (fly ash), irrespective of the replacement ratio. Sánchez de Rojas et al. [76, 77] and Rodríguez et al. [73], analysing additions with higher pozzolanic activity such as spent FCC and paper sludge, observed that for replacement ratios of $20 \%$ or higher, heat of hydration declined due to the slower pozzolanic reactivity resulting from the shortage of portlandite in the mortars.

In light of the foregoing, OPC $+20 \% \mathrm{AF}$ can be regarded as a low heat cement and classified as CEM type II/A 42.5R LH, inasmuch as its $41 \mathrm{~h}$ heat of hydration value was lower than $270 \mathrm{~J} / \mathrm{g}$.

\subsection{Colour}

The colour coordinates for the anhydrous cements and the granite quarry dust are shown in Figure 11. Although all three cements lay in a range $\left(0-0.03\left(a^{*}\right), 8.4-9\left(b^{*}\right)\right)$ indicative of grey tones [78], the addition of granite quarry dust induced a slight shift to the right in the chromatic 
quadrant defined by the $+a^{*} /+b^{*}$ axes. A similar shift was recorded by other authors assessing the effect of adding paper sludge [79] or coal mining waste [80] to cement raw mixes.

Figure 11 . Colour coordinates $\left(a^{*}, b^{*}\right)$ for the anhydrous cements and granite quarry dust Adding granite dust, with a lightness $\left(L^{*}\right)$ value of $77.1 \%$, to the cement raised $L^{*}$ from the $65.4 \%$ recorded for OPC to $68.3 \%$ in OPC+10\%AF and $69.5 \%$ in OPC+20\%AF.

The increase in lightness toward $100 \%$ (white) was linearly correlated to the replacement ratio further to the equation $y=0.20 x+65.73\left(R^{2}=0.941\right)$, where $y$ is lightness and $x$ the percentage of the addition in the cements.

\subsection{Statistical analysis}

The results of the bivariate analyses of the variables studied are listed in Table 5. The data given for each variable include Pearson's correlation coefficient $\left(R^{2}\right)$, a measure of the strength of the linear relationship between two variables (which is strongest when closest to one of the two extreme values, +1 and -1 ); and the $p$-value, an indication of the statistical significance of the correlation between variables (assuming significance at $p<0.05$ ) at a confidence level of $95 \%$.

\section{Table 5. Bivariate analysis data}

The variables (properties) water absorption, capillary absorption, electrical resistivity, shrinkage, expansion and heat of hydration were all observed to be inter-related, and related as well to the mechanical properties studied. The correlations obtained for the variables water absorption, density and compressive strength were consistent with findings reported by Baeza et al. [63] for mortars prepared with binary and ternary cements.

The multivariate analysis of variance (MANOVA) findings on the effect of the factors time and replacement ratio on the variables electrical resistivity, water absorption, capillary water absorption, expansion, shrinkage, alkali-silica reaction and heat of hydration are given in Table 6. The statistical model applied explained from $65 \%$ to $99 \%$ of the variability observed, depending on the variable analysed.

Table 6. Multivariate analysis of variance (MANOVA) data The data showed that replacement ratio and age had significant effects $(p<0.05)$ on all the variables analysed, as observed in the findings discussed above. The interaction between replacement ratio and age also had a significant effect $(p<0.05)$ on the variables electrical 
resistivity, drying shrinkage and heat of hydration. Interaction between the two factors was not significant for any of the other variables studied, however $(p=1>0.05)$.

\section{CONCLUSIONS}

The conclusions that may be drawn from this study are set out below.

- New cements bearing $10 \%$ or $20 \%$ granite quarry dust meet the strength requirements laid down in the standards in place for cement type II/A, strength class $42.5 \mathrm{~N}$ or $42.5 \mathrm{R}$.

- When included in cement, the waste induces a small rise ( $\approx 17 \%)$ in electrical resistivity and raises the $q$ (ageing factor) value, affording the resulting mortars greater protection against corrosion than available to conventional materials.

- The new cements exhibit slightly higher total (15\%) and capillary (14\%) absorption than the reference OPC.

- The partial replacement of cement with granite quarry dust reduces drying shrinkage and expansion in the new materials, lowering the risk of early age cracking that could compromise their durability and shorten their service life.

- As granite quarry dust exhibits no alkali-silica reactivity, it is apt for use in cement manufacture.

- Heat of hydration is $19 \%$ lower in OPC+20\%AF cement than in OPC, narrowing the likelihood of early age cracking.

- $\quad$ Binders bearing $20 \%$ granite quarry dust meet the requirements to qualify as low heat cements (CEM II/A LH).

- The new cements have higher $L^{*}$ values than OPC, rendering them apt for aesthetically sensitive applications.

In short, granite quarry dust induces no substantial change in the durability parameters assessed and is apt for use in the design of new type II/A conventional as well as type II/A special low heat cements. The present findings to that effect further the institution of the circular economy in the cement industry.

\section{Acknowledgements}

This study was funded by the Spanish Ministry of Science and Innovation under projects BIA 2013-48876-C3-1-R, BIA 2013-48876-C3-2-R and BIA2016-76643-C3-1-R, as well as by the 
Government of Extremadura and the European Regional Development Fund (ERDF) under grant GR 15064 awarded to the MATERIA research group.

\section{References}

[1] CEMBUREAU, Activity report 2016, Brussels, https://cembureau.eu/media/1635/activityreport-2016.pdf , 2017 [accessed date: 2018/01/30].

[2] S. Singh, N. Nande, P. Bansal, R. Nagar, Experimental Investigation of Sustainable Concrete Made with Granite Industry By-Product, J. Mater. Civ. Eng. 29 (2017) 040117017.

[3] D.W.S. Ho, A.M.M. Sheinn, C.C. Ng, C.T. Tam, The use of quarry dust for SCC applications, Cem. Concr. Res. 32 (2002) 505-511.

[4] N.K. Sharma, P. Kumar, S. Kumar, B.S. Thomas, R.C. Gupta, Properties of concrete containing polished granite waste as partial substitution of coarse aggregate, Constr. Build. Mater. 151 (2017) 158-163.

[5] P. Kathirvel, V. Saraswathy, S.P. Karthik, A.S.S. Sekar, Strength and Durability Properties of Quaternary Cement Concrete Made with Fly Ash, Rice Husk Ash and Limestone Powder, Arab. J. Sci. Eng. 38 (2013) 589-598.

[6] I. Marmol, P. Ballester, S. Cerro, G. Monros, J. Morales, L. Sanchez, Use of granite sludge wastes for the production of coloured cement-based mortars, Cem. Concr. Compos. 32 (2010) 617-622.

[7] A.E.M. Abd Elmoaty, Mechanical properties and corrosion resistance of concrete modified with granite dust, Constr. Build. Mater. 47 (2013) 743-752.

[8] S.A. Abukersh, C.A. Fairfield, Recycled aggregate concrete produced with red granite dust as a partial cement replacement, Constr. Build. Mater. 25 (2011) 4088-4094.

[9] T. Ramos, A.M. Matos, B. Schmidt, J. Rio, J. Sousa-Coutinho, Granitic quarry sludge waste in mortar: Effect on strength and durability, Constr. Build. Mater. 47 (2013) 1001-1009.

[10] J.B.M. Dassekpo, X. Zha, J. Zhan, Compressive strength performance of geopolymer paste derived from Completely Decomposed Granite (CDG) and partial fly ash replacement, Constr. Build. Mater. 138 (2017) 195-203.

[11] P. Torres, H.R. Fernandes, S. Olhero, J.M.F. Ferreira, Incorporation of wastes from granite rock cutting and polishing industries to produce roof tiles, J. Eur. Ceram. Soc. 29 (2009) 23-30. 
[12] C. Medina, M. I. Sánchez de Rojas, C. Thomas, J. A. Polanco, M. Frías, Durability of recycled concrete made with recycled ceramic sanitary ware aggregate. Inter-indicator relationships, Constr. Build. Mater. 105 (2016) 480-486.

[13] C. Di Bella, M. Wyrzykowski, P. Lura, Evaluation of the ultimate drying shrinkage of cement-based mortars with poroelastic models, Mater. Struct. 50 (2017).

[14] B.R. Murlidhar, E.T. Mohamad, D.J. Armaghani, Potential alkali silica reactivity of various rock types in an aggregate granite quarry, Measurement 81 (2016) 221-231.

[15] C. Medina, I.F. Sáez del Bosque, E. Asensio, M. Frías, M.I. Sánchez de Rojas, New additions for eco-efficient cement design. Impact on calorimetric behaviour and comparison of test methods, Mater. Struct. 49 (2016) 4595-4607.

[16] G. Medina, I.F. Sáez del Bosque, M. Frías, M.I. Sánchez de Rojas, C. Medina, Mineralogical study of granite waste in a pozzolan/Ca(OH)2 system: Influence of the activation process, Appl. Clay Sci. 135 (2017) 362-371.

[17] European Committee for Standardization, EN 196-1. Methods of testing cement - Part 1: Determination of strength.

[18] European Committee for Standardization, EN 197-1. Cement. Composition, specifications and conformity criteria for common cements.

[19] G. Medina, I.F. Sáez del Bosque, M. Frías, M.I. Sánchez de Rojas, C. Medina, Granite quarry waste as a future eco-efficient supplementary cementitious material (SCM): Scientific and technical considerations, J. Clean Prod. 148 (2017) 467-476.

[20] American Society for Testing and Materials, D 4404-84: Test method for determination of pore volume and pore volume distribution of soil and rock by mercury intrusion porosimetry.

[21] International Commission on Illumination, Technical Report: Colorimetry, third edition, CIE, 2014.

[22] A.O. Mashaly, B.A. El-Kaliouby, B.N. Shalaby, A.M. El - Gohary, M.A. Rashwan, Effects of marble sludge incorporation on the properties of cement composites and concrete paving blocks, J. Clean Prod. 112 (2016) 731-741.

[23] T. Kulovana, J. Pokorny, M. Keppert, Z. Pavlik, R. Cerny, Strength Development and Physical Properties of Cement Paste with Incorporated Ceramic Powder, Mater. Sci.-Medzg. 22 (2016) 82-87. 
[24] P. Kumar Metha, P.J.M. Monteiro, Concrete: Microstructure, Properties and Materials, Third Edition ed., McGraw-Hill, United States of America, 2006, pp. 659.

[25] K. Vardhan, S. Goyal, R. Siddique, M. Singh, Mechanical properties and microstructural analysis of cement mortar incorporating marble powder as partial replacement of cement, Constr. Build. Mater. 96 (2015) 615-621.

[26] M. Frias, R. Vigil de la Villa, R. Garcia, I. de Soto, C. Medina, M.I. Sanchez de Rojas, Scientific and technical aspects of blended cement matrices containing activated slate wastes, Cem. Concr. Compos. 48 (2014) 19-25.

[27] C.W. Hong, J.I. Lee, J.H. Ryu, Effects of recycled copper slag as cementitious material in ordinary Portland cement mortar, J. Ceram. Process. Res. 17 (2016) 768-772.

[28] H.Y. Wang, C.C. Wang, S.C. Chang, J.C. Lin, A study of engineering and electricity properties of cement mortar added with recycled materials and piezoelectric powders, Constr. Build. Mater. 113 (2016) 297-305.

[29] J. Rissanen, K. Ohenoja, P. Kinnunen, M. Illikainen, Partial Replacement of PortlandComposite Cement by Fluidized Bed Combustion Fly Ash, J. Mater. Civ. Eng. 29 (2017).

[30] M. Frias, M.I. Sánchez de Rojas, J. Santamaría, C. Rodríguez, Recycling of silicomanganese slag as pozzolanic material in Portland cements: Basic and engineering properties, Cem. Concr. Res. 36 (2006) 487-491.

[31] Z. Yu, J. Ma, G. Ye, K. van Breugel, X. Shen, Effect of fly ash on the pore structure of cement paste under a curing period of 3 years, Constr. Build. Mater. 144 (2017) 493-501.

[32] S. Rukzon, P. Chindaprasirt, Strength, porosity, and chloride resistance of mortar using the combination of two kinds of pozzolanic materials, Int. J. Miner. Metall. Mater. 20 (2013) 808814.

[33] M. Cabrera, F. Agrela, J. Ayuso, A.P. Galvin, J. Rosales, Feasible use of biomass bottom ash in the manufacture of cement treated recycled materials, Mater. Struct. 49 (2016) 32273238.

[34] Z. Chen, C. S. Poon, Comparative studies on the effects of sewage sludge ash and fly ash on cement hydration and properties of cement mortars, Constr. Build. Mater. 154 (2017) 791803. 
[35] J.C. Arenas-Piedrahita, P. Montes-García, J.M. Mendoza-Rangel, H.Z. López Calvo, P.L. Valdez-Tamez, J. Martínez-Reyes, Mechanical and durability properties of mortars prepared with untreated sugarcane bagasse ash and untreated fly ash, Constr. Build. Mater. 105 (2016) 69-81.

[36] A. Joshaghani, M. A. Moeini, Evaluating the effects of sugar cane bagasse ash (SCBA) and nanosilica on the mechanical and durability properties of mortar, Constr. Build. Mater. 152 (2017) 818-831.

[37] G. Fajardo, P. Valdez, J. Pacheco, Corrosion of steel rebar embedded in natural pozzolan based mortars exposed to chlorides, Constr. Build. Mater. 23 (2009) 768-774.

[38] J.M. Cruz, J. Payá, L.F. Lalinde, I.C. Fita, Evaluation of electric properties of cement mortars containing pozzolans, Mater. Constr. 61 (2011) 7-26.

[39] A.L.G. Gastaldini, G.C. Isaia, T.F. Hoppe, F. Missau, A.P. Saciloto, Influence of the use of rice husk ash on the electrical resistivity of concrete: A technical and economic feasibility study, Constr. Build. Mater. 23 (2009) 3411-3419.

[40] D.A. Whiting, M.A. Nagi, Electrical Resistivity of Concrete - A Literature Review, Portland Cement Association, Skokie, Illinois, USA, 2003, pp. 57.

[41] V. Baroghel-Bouny, K. Kinomura, M. Thiery, S. Moscardelli, Easy assessment of durability indicators for service life prediction or quality control of concretes with high volumes of supplementary cementitious materials, Cem. Concr. Compos. 33 (2011) 832-847.

[42] Z. Liu, Y. Zhang, Q. Jiang, Continuous tracking of the relationship between resistivity and pore structure of cement pastes, Constr. Build. Mater. 53 (2014) 26-31.

[43] C. Andrade, R. d'Andréa, in: Pro061. International Conference on Microstructure Related Durability of Cementitious Composites, K.B.W. Sun, C. Miao, G. Ye and H. Chen, (Ed.) RILEM Publications: Delft, The Netherlands, 2008; pp 1483-1490.

[44] C. Andrade, R.D’Andrea, La resistividad eléctrica como parámetro de control del hormigón y su durabilidad, ALCONPAT, Mérida (México), 2011, pp. 93-101.

[45] Comisión Permanente del Hormigón, Instrucción Hormigón Estructural. EHE-08 (Spanish Code on Structural Concrete), Madrid, 2008, pp. 704.

[46] International Federation for Structural Concrete, fib Model Code For Concrete Structures 2010, Lausanne, Switzerland, 2010, pp. 318. 
[47] S. Helland, Design for service life: implementation of fib Model Code 2010 rules in the operational code ISO 16204, Struct. Concr. 14 (2013) 10-18.

[48] C. Andrade, J. Fullea, C. Alonso, Measurement and Interpretation of the on-Site Corrosion Rate, C. Andrade, C. Alonso, J. Fullea, (Eds.) 2000; Vol. 18, pp 157-165.

[49] W. Zhang, Y. Hama, S.H. Na, Drying shrinkage and microstructure characteristics of mortar incorporating ground granulated blast furnace slag and shrinkage reducing admixture, Constr. Build. Mater. 93 (2015) 267-277.

[50] A. Hamood, J.M. Khatib, C. Williams, The effectiveness of using Raw Sewage Sludge (RSS) as a water replacement in cement mortar mixes containing Unprocessed Fly Ash (u-FA), Constr. Build. Mater. 147 (2017) 27-34.

[51] W.T. Lin, A. Cheng, R. Huang, Y.C. Wu, T.Y. Han, Rock wool wastes as a supplementary cementitious material replacement in cement-based composites, Comput. Concr. 11 (2013) 93104.

[52] X. Hu, C.J. Shi, Z.G. Shi, B.H. Tong, D.H. Wang, Early age shrinkage and heat of hydration of cement-fly ash-slag ternary blends, Constr. Build. Mater. 153 (2017) 857-865.

[53] Y. H. Kwon, S. H. Kang, S. G. Hong, J. Moon, Acceleration of Intended Pozzolanic Reaction under Initial Thermal Treatment for Developing Cementless Fly Ash Based Mortar, Materials $10(2017) 225$.

[54] M. Lenart, Assessment of mortar shrinkage in aspect of organic and inorganic modifiers use, 7th Scientific-Technical Conference on Material Problems in Civil Engineering (Matbud'2015) 108 (2015) 309-315.

[55] M. Fernández Cánovas, Hormigón, Octava Edición ed., Colegio de Ingenieros de Caminos, Canales y Puertos, Madrid, 2007, pp. 666.

[56] P. Martauz, I. Janotka, J. Strigac, M. Bacuvcik, Fundamental properties of industrial hybrid cement: utilization in ready-mixed concretes and shrinkage-reducing applications, Mater. Constr. 66 (2016).

[57] Spanish Committee for Standardization, UNE 146508:1999 EX. Test for aggregates. Determination of the alkali-silica and alkali-silicate potencial reactivity of aggregates. Accelerated mortar bar test. 
[58] V. Ramos, I. Fernandes, A.S. Silva, D. Soares, B. Fournier, S. Leal, F. Noronha, Assessment of the potential reactivity of granitic rocks - Petrography and expansion tests, Cem. Concr. Res. 86 (2016) 63-77.

[59] Y. Kawabata, K. Yamada, Evaluation of Alkalinity of Pore Solution Based on the Phase Composition of Cement Hydrates with Supplementary Cementitious Materials and its Relation to Suppressing ASR Expansion, J. Adv. Concr. Technol. 13 (2015) 538-553.

[60] S. Al-Fadala, J. Chakkamalayath, S. Al-Bahar, A. Al-Aibani, S. Ahmed, Significance of performance based specifications in the qualification and characterization of blended cement using volcanic ash, Constr. Build. Mater. 144 (2017) 532-540.

[61] A.K. Saha, P.K. Sarker, Expansion due to alkali-silica reaction of ferronickel slag fine aggregate in OPC and blended cement mortars, Constr. Build. Mater. 123 (2016) 135-142.

[62] N.F. Abas, M.A. Karim, Properties of mortar blocks with waste concrete ash (WCA) as a cement replacement, Jurnal Teknologi 75 (2015) 13-18.

[63] F. Baeza, J. Paya, O. Galao, J.M. Saval, P. Garces, Blending of industrial waste from different sources as partial substitution of Portland cement in pastes and mortars, Constr. Build. Mater. 66 (2014) 645-653.

[64] C. Medina, M.I. Sánchez de Rojas, M. Frías, Properties of recycled ceramic aggregate concretes: Water resistance, Cem. Concr. Compos. 40 (2013) 21-29.

[65] N. S. Martys, C. F. Ferraris, Capillary transport in mortars and concrete, Cem. Concr. Res. 27 (1997) 747-760.

[66] J. Rosales, M. Cabrera, M.G. Beltran, M. Lopez, F. Agrela, Effects of treatments on biomass bottom ash applied to the manufacture of cement mortars, J. Clean Prod. 154 (2017) $424-435$.

[67] T.A. Ostnor, H. Justnes, Durability of mortar with calcined marl as supplementary cementing material, Adv. Cem. Res. 26 (2014) 344-352.

[68] A. Benli, M. Karatas, Y. Bakir, An experimental study of different curing regimes on the mechanical properties and sorptivity of self-compacting mortars with fly ash and silica fume, Constr. Build. Mater. 144 (2017) 552-562. 
[69] J. Marcos, J. Sánchez, M.A. Climent, Advances in Modeling Concrete Service Life. Proceeding of 4th International RILEM PhD Workshop held in Madrid, J. G. C. Andrade, (Ed.) New York, 2010; pp 21-31.

[70] C. Hall, W.D. Hoff, S.C. Taylor, M.A. Wilson, B.G. Yoon, H.W. Reinhardt, M. Sosoro, P. Meredith, A.M. Donald, Water anomaly in capillary liquid absorption by cement-based materials, J. Mater. Sci. Lett. 14 (1995) 1178-1181.

[71] L. Hanzic, L. Kosec, I. Anzel, Capillary absorption in concrete and the Lucas-Washbum equation, Cem. Concr. Compos. 32 (2010) 84-91.

[72] G. Fagerlund, On the capillarity of concrete, 1982, pp. 20.

[73] O. Rodriguez, M. Frias, M.I. Sanchez de Rojas, Influence of the calcined paper sludge on the development of hydration heat in blended cement mortars, J. Therm. Anal. Calorim. 92 (2008) 865-871.

[74] M. Frias, M.I. Sánchez de Rojas, J. Cabrera, The effect that the pozzolanic reaction of metakaolin has on the heat evolution in metakaolin-cement mortars, Cem. Concr. Res. 30 (2000) 209-216.

[75] D.G. Snelson, S. Wild, M. O'Farrell, Heat of hydration of Portland Cement-Metakaolin-Fly ash (PC-MK-PFA) blends, Cem. Concr. Res. 38 (2008) 832-840.

[76] M.G. de Lomas, M.I. Sánchez de Rojas, M. Frias, Pozzolanic reaction of a spent fluid catalytic cracking catalyst in FCC-cement mortars, J. Therm. Anal. Calorim. 90 (2007) 443-447. [77] M.I. Sánchez de Rojas, M. Frías, The pozzolanic activity of different materials, its influence on the hydration heat in mortars, Cem. Concr. Res. 26 (1996) 203-213.

[78] G. Wyszecki, W.S. Stiles, Color science: concepts and methods, quantitative data and formulae. Second Edition, John Wiley \& Sons, Inc, United States of America, 1982, pp. 950.

[79] A. Kappel, L.M. Ottosen, G.M. Kirkelund, Colour, compressive strength and workability of mortars with an iron rich sewage sludge ash, Constr. Build. Mater. 157 (2017) 1199-1205.

[80] M. Frias, M.I. Sanchez de Rojas, R. Garcia, A. Juan Valdes, C. Medina, Effect of activated coal mining wastes on the properties of blended cement, Cem. Concr. Compos. 34 (2012) 678683. 
Table 1. Physical, mechanical and durability variables studied

\begin{tabular}{|c|c|c|c|}
\hline Property & Standard & $\begin{array}{l}\text { Specimen size } \\
(\mathrm{cm})\end{array}$ & $\begin{array}{c}\text { Water/ } \\
\text { cement ratio }\end{array}$ \\
\hline Bulk density & - & \multirow{5}{*}{$4 \times 4 \times 16$} & \multirow{5}{*}{0.50} \\
\hline $\begin{array}{l}\text { Compressive and flexural } \\
\text { strength }\end{array}$ & EN 196-1 [17] & & \\
\hline Electrical resistivity & UNE 83988 [20] & & \\
\hline Total water absorption & UNE 83980 [21] & & \\
\hline Capillary absorption & UNE 83982 [22] & & \\
\hline Drying shrinkage & \multirow{2}{*}{ UNE 80112 [23] } & \multirow{3}{*}{$2.5 \times 2.5 \times 28.5$} & \multirow{3}{*}{0.47} \\
\hline Water-induced swelling & & & \\
\hline Alkali-silica reaction & $\begin{array}{l}\text { UNE } 146508 \\
\text { [24] }\end{array}$ & & \\
\hline Calorimetry & EN 196-9 [25] & - & 0.40 \\
\hline Colour & UNE 80117 & $4 \times 4 \times 16$ & 0.50 \\
\hline
\end{tabular}

Table 2. Bulk density and mechanical performance in $28 \mathrm{~d}$ mortars

\begin{tabular}{|l|c|c|c|}
\hline \multirow{2}{*}{\multicolumn{1}{c|}{ Property }} & \multicolumn{3}{c|}{ Mortar } \\
\cline { 2 - 4 } & OPC & OPC+10\%AF & OPC\%+20\%AF \\
\hline Bulk density $\left(\mathrm{kg} / \mathrm{m}^{3}\right)$ & $2284.51 \pm 2.71$ & $2282.68 \pm 0.76$ & $2280.86 \pm 2.20$ \\
\hline Compressive strength $(\mathrm{MPa})$ & $65.67 \pm 1.27$ & $58.08 \pm 1.07$ & $51.12 \pm 0.94$ \\
\hline Flexural strength $(\mathrm{MPa})$ & $9.65 \pm 0.08$ & $8.68 \pm 0.29$ & $7.97 \pm 0.63$ \\
\hline
\end{tabular}

Table 3. Total porosity and pore size distribution in $28 \mathrm{~d}$ mortars

\begin{tabular}{|c|c|c|c|c|}
\hline \multirow{2}{*}{\multicolumn{2}{|c|}{ Property (\%vol.) }} & \multicolumn{3}{|c|}{ Mortar } \\
\hline & & OPC & OPC $+10 \% A F$ & OPC $\%+20 \% A F$ \\
\hline \multirow{2}{*}{\multicolumn{2}{|c|}{ Total porosity }} & 12.52 & 12.94 & 13.44 \\
\hline & & \multicolumn{3}{|c|}{$y=0.05 x+12.51\left[R^{2}=0.99\right]$} \\
\hline \multirow{2}{*}{\multicolumn{2}{|c|}{ Macropores $(>0.05 \mu \mathrm{m})$}} & 9.85 & 9.94 & 10.14 \\
\hline & & \multicolumn{3}{|c|}{$z=0.02 x+9.83\left[R^{2}=0.96\right]$} \\
\hline \multirow{2}{*}{\multicolumn{2}{|c|}{ Capillary pores $(0.007<\phi<0.05 \mu \mathrm{m})$}} & 2.27 & 2.73 & 2.81 \\
\hline & & \multicolumn{3}{|c|}{$j=0.03 x+2.33\left[R^{2}=0.86\right]$} \\
\hline \multirow{2}{*}{ Pores } & $\phi>0.10 \mu \mathrm{m}$ & 5.50 & 6.73 & 7.10 \\
\hline & $\phi<0.10 \mu \mathrm{m}$ & 6.62 & 5.94 & 5.86 \\
\hline
\end{tabular}


Table 4. Total water absorption, capillary absorption coefficient and peak temperature in the mortars studied

\begin{tabular}{|l|c|c|c|}
\hline \multirow{2}{*}{ Property } & \multicolumn{3}{c|}{ Mortar } \\
\cline { 2 - 4 } & OPC & OPC+10\%AF & OPC+20\%AF \\
\hline Water absorption (\%) & 4.99 & 5.35 & 5.73 \\
\hline Capillary absorption coefficient $\left(10^{-4} \mathrm{~kg} / \mathrm{min}^{0.5} \mathrm{~m}^{2}\right)$ & 2.90 & 3.21 & 3.32 \\
\hline Peak temperature $\left({ }^{\circ} \mathrm{C}\right)$ & 32.70 & 30.90 & 26.40 \\
\hline
\end{tabular}

Table 5. Bivariate analysis data

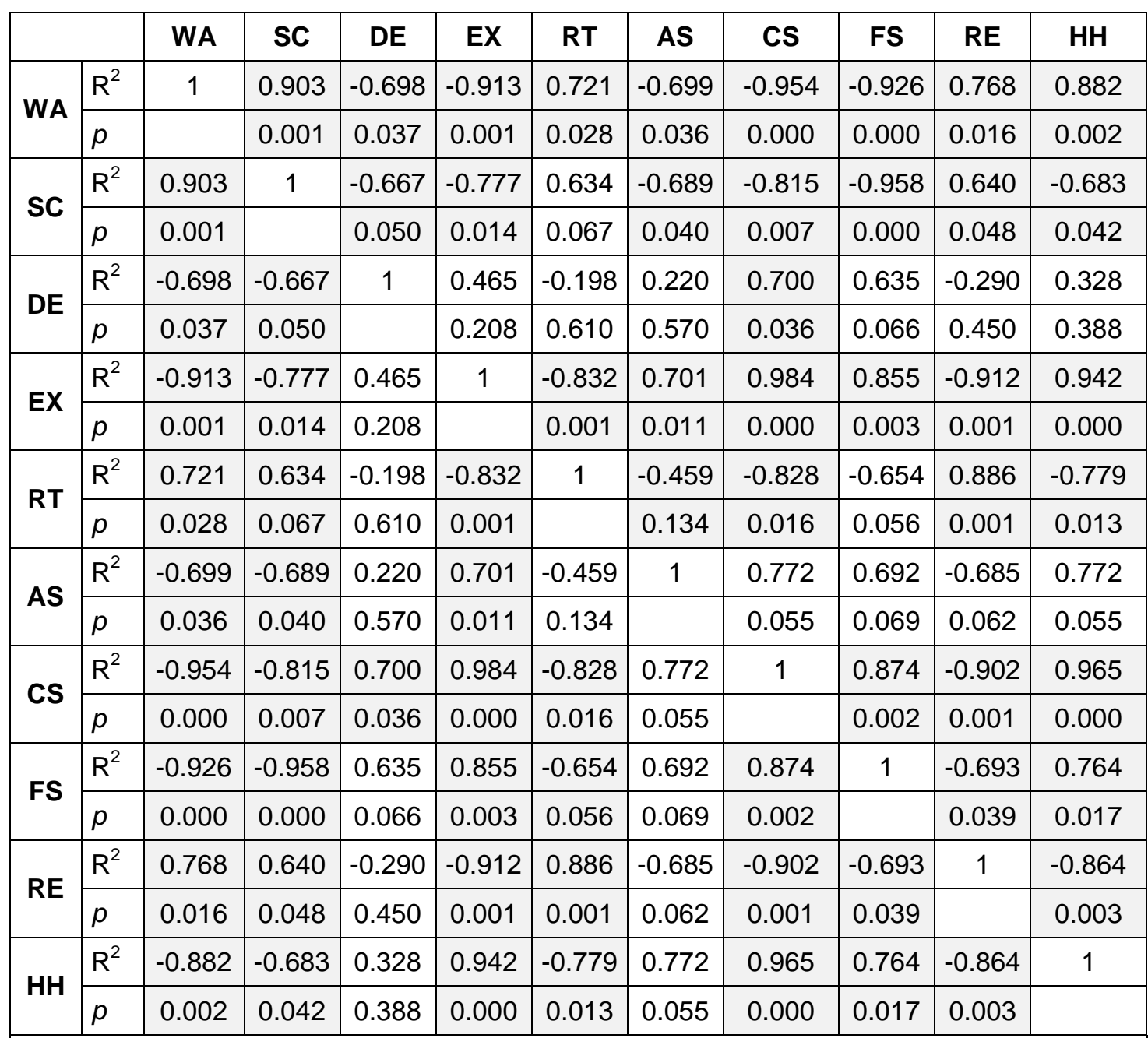

Note. - WA: water absorption; SC: capillary absorption coefficient; DE: density; EX: expansion; RT: drying shrinkage; AS: alkali-silica reaction; CS: compressive strength; $F S$ : flexural strength; RE: electrical resistivity; $\boldsymbol{H H}$ : heat of hydration; $\boldsymbol{p}$ : $\boldsymbol{p}$-value; $\boldsymbol{R}^{2}$ : Pearson's correlation coefficient. Shading denotes statistical significance. 


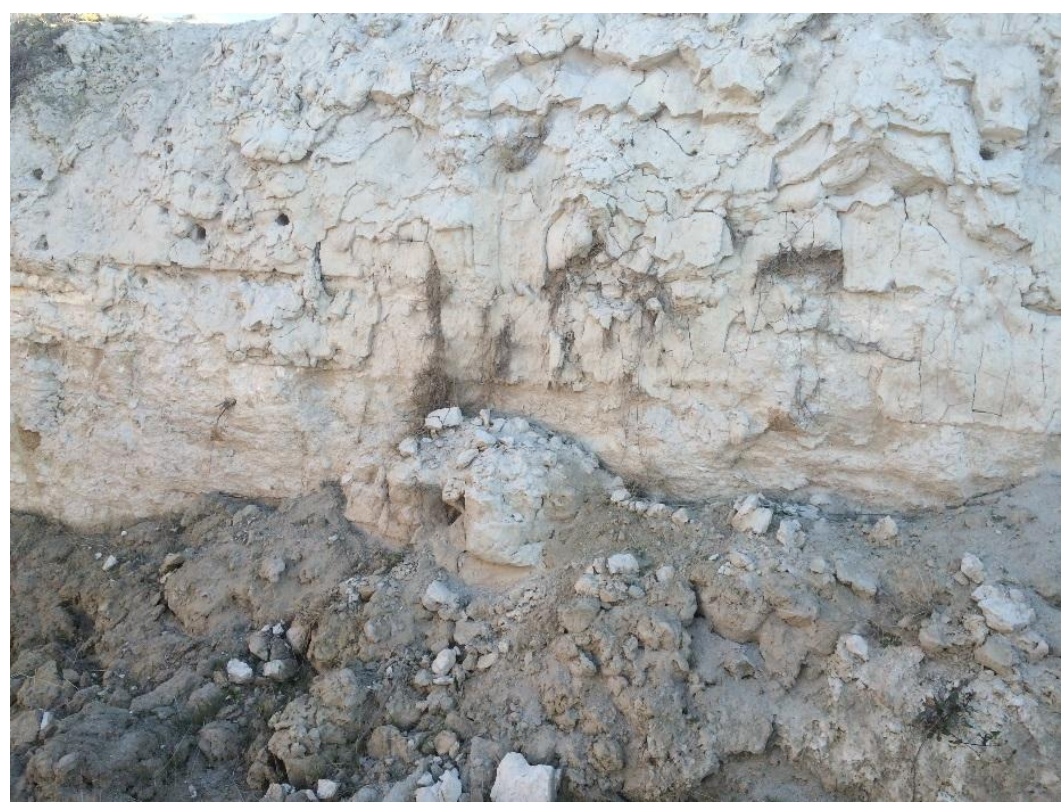

Figure 1. Stockpiled granite quarry dust

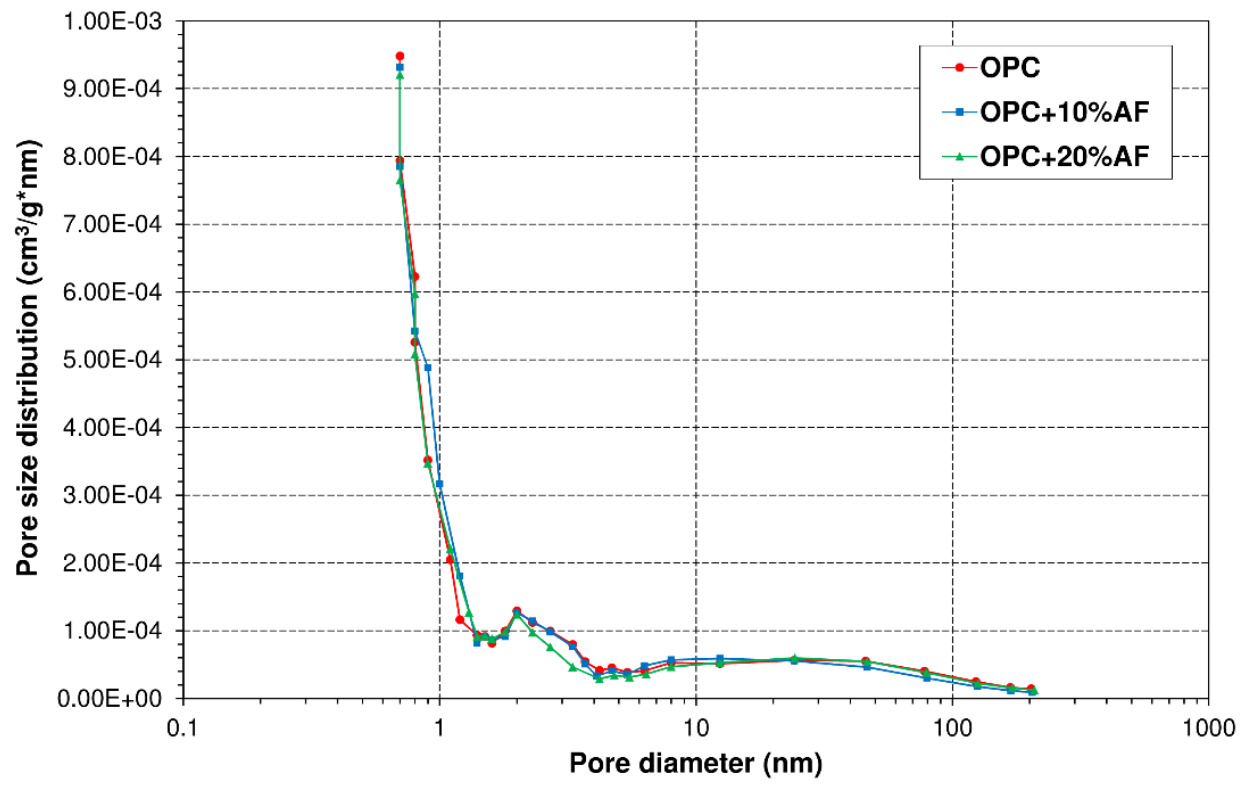

Figure 2. Pore size distribution for cements OPC, OPC+10\%AF and OPC+20\%AF 


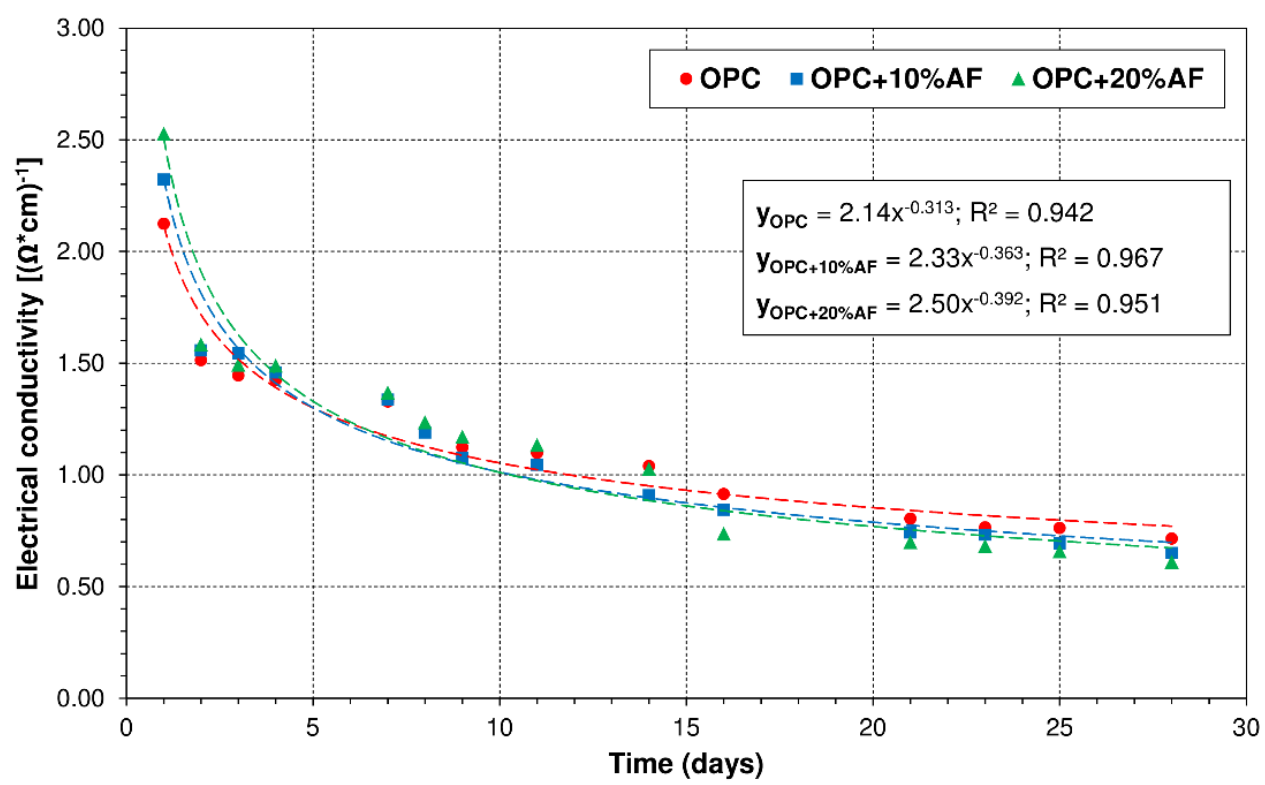

Figure 3. Electrical conductivity versus time



Figure 4. Drying shrinkage in mortars dried in air for $40 \mathrm{~d}$ at $20^{\circ} \mathrm{C}$ and $60 \% \mathrm{RH}$ 


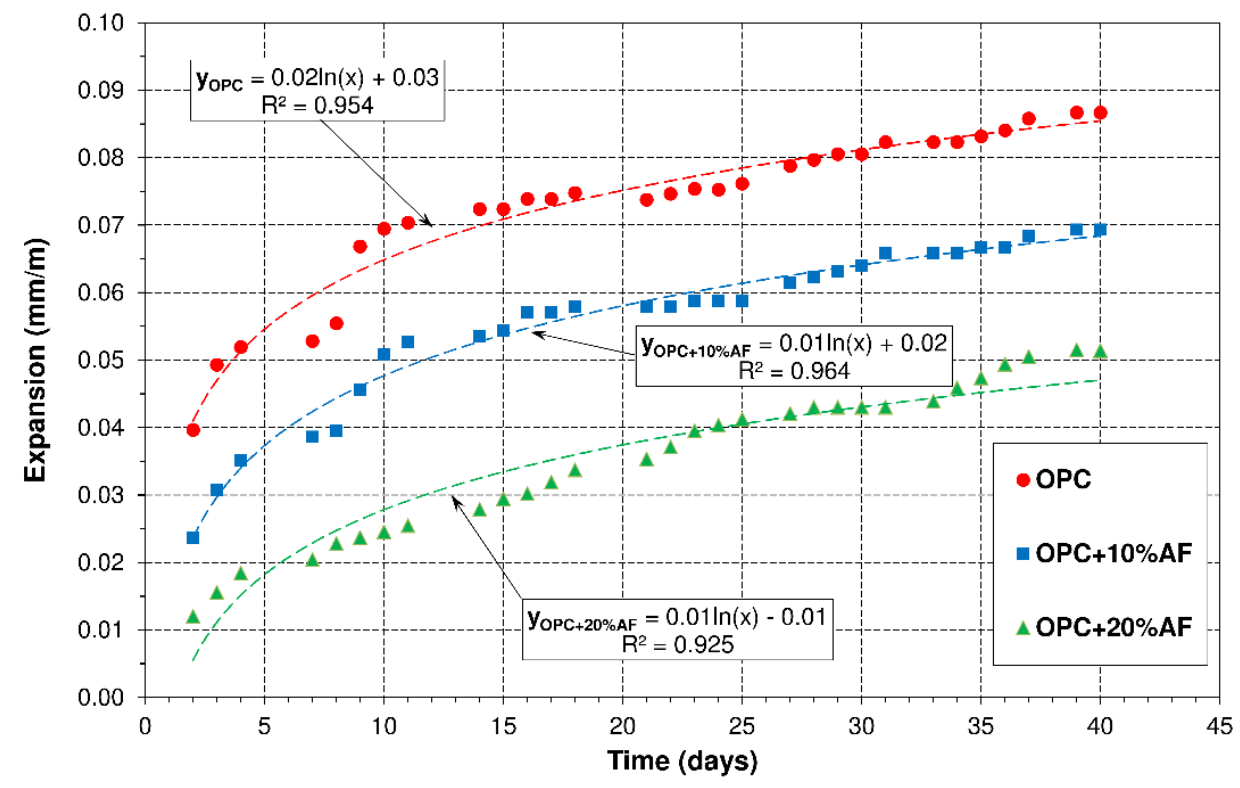

Figure 5. Expansion in mortars immersed in water at $20^{\circ} \mathrm{C}$

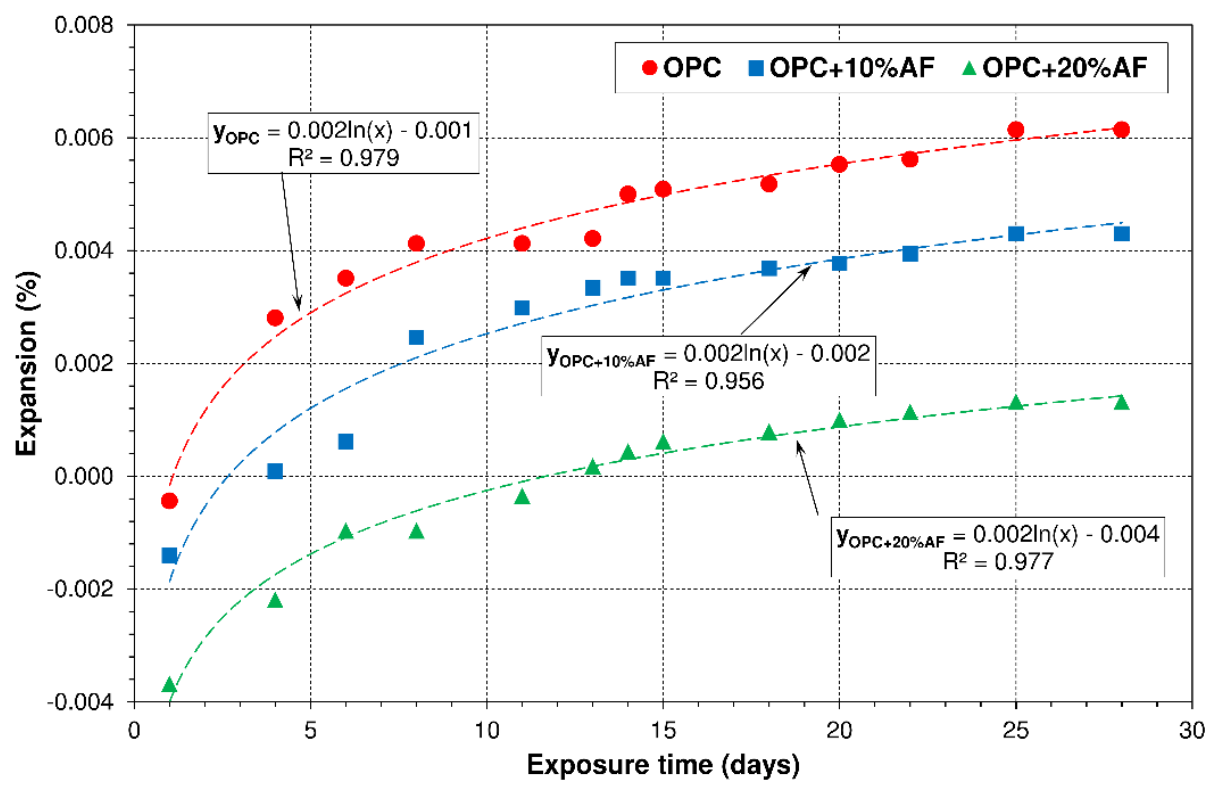

Figure 6. Expansion in mortars immersed in a $1 \mathrm{~N} \mathrm{NaOH}$ solution at $80^{\circ} \mathrm{C}$ 

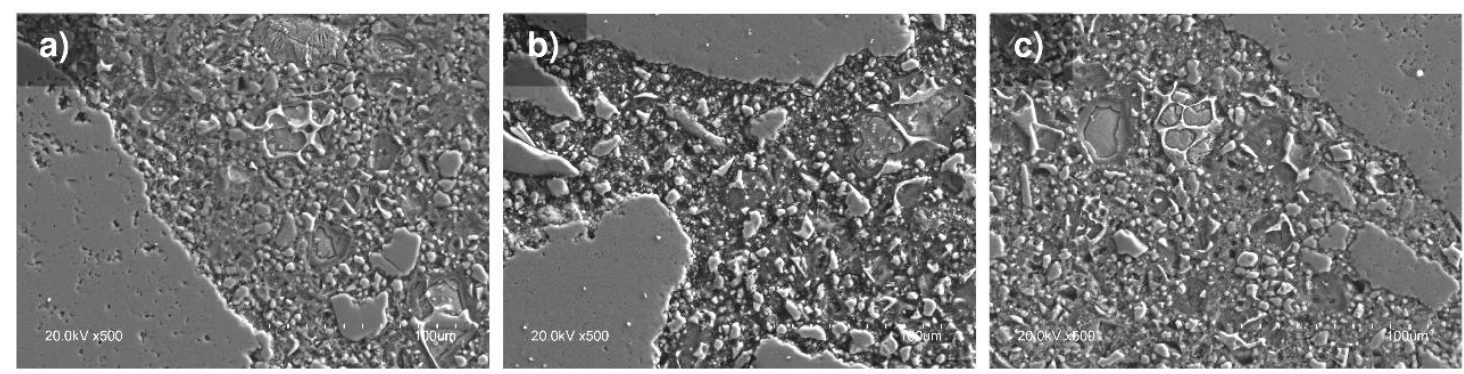

Figure 7. BSE micrographs (500x) of mortars tested for $28 \mathrm{~d}$ for the alkali-silica reaction: a) $\mathrm{OPC}$; b) OPC+10\%AF; c) OPC+20\%AF

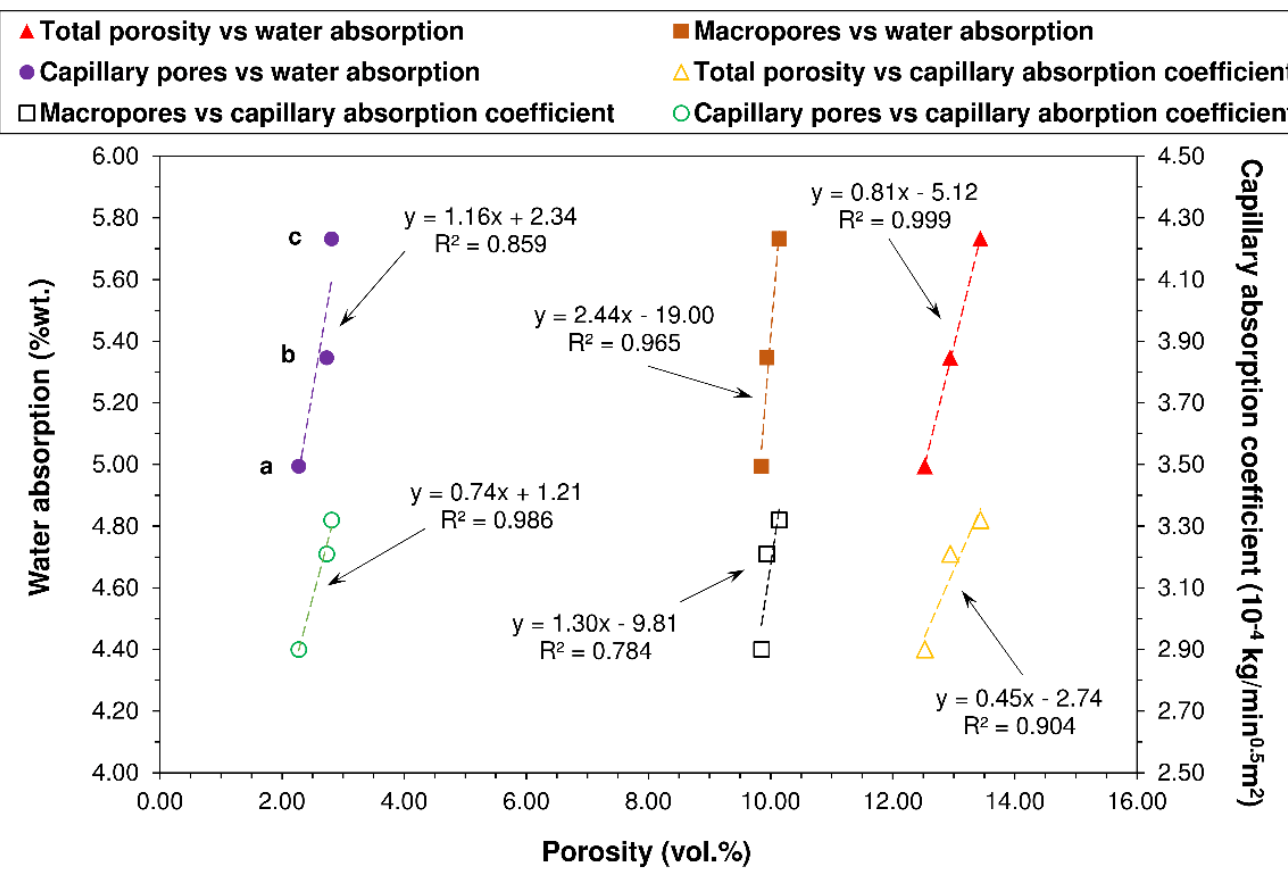

Figure 8. Water absorption and capillary absorption coefficient versus porosity: a) OPC; b) $\mathrm{OPC}+10 \% \mathrm{AF}$; c) $\mathrm{OPC}+20 \% \mathrm{AF}$ 


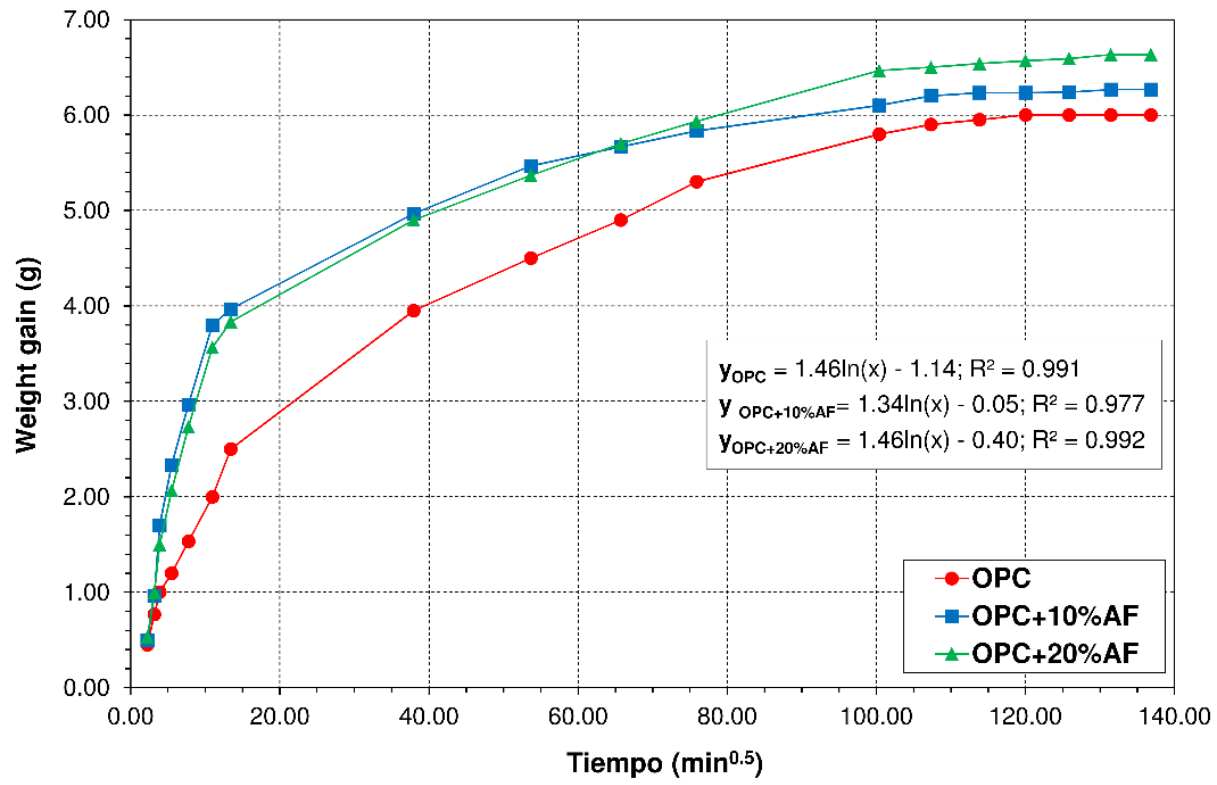

Figure 9. Capillary absorption curves in mortars

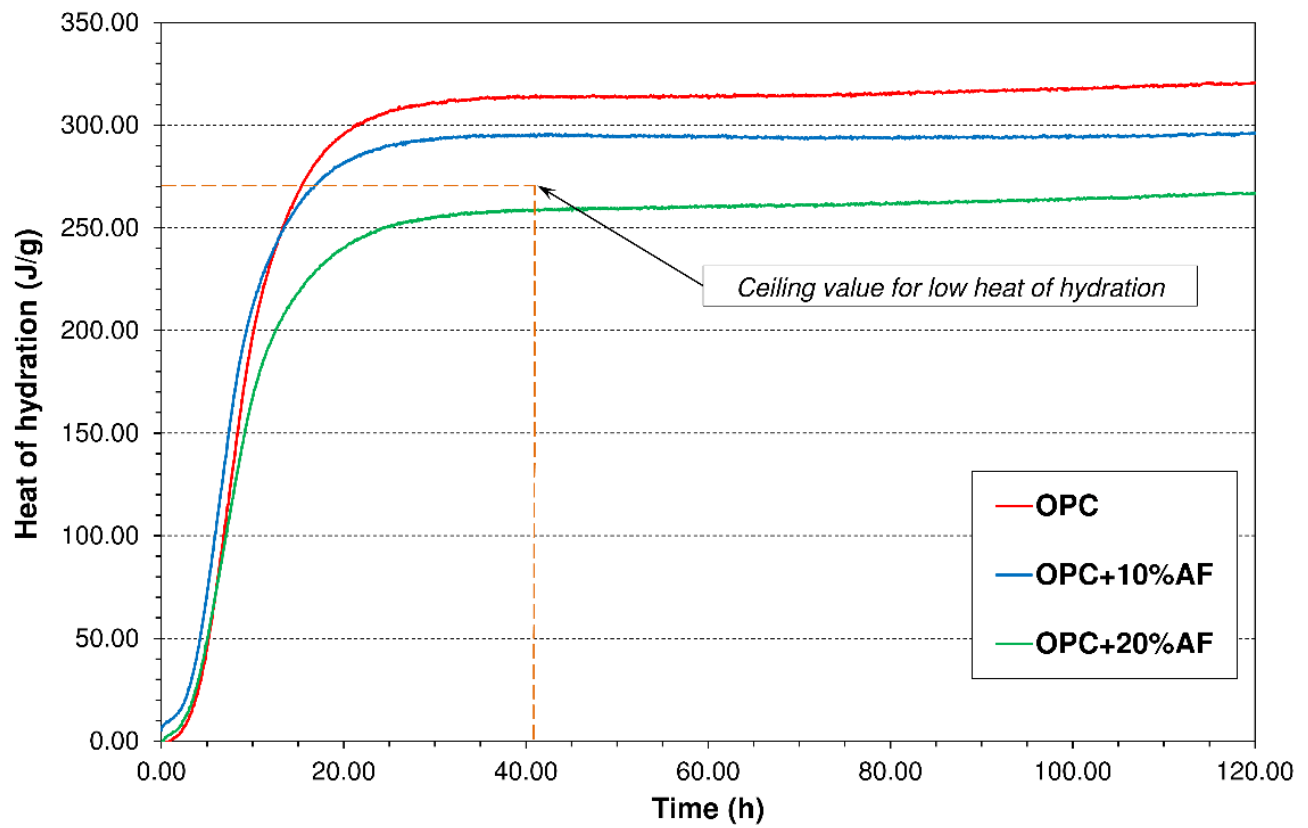

Figure 10. Total heat of hydration in mortars versus time 


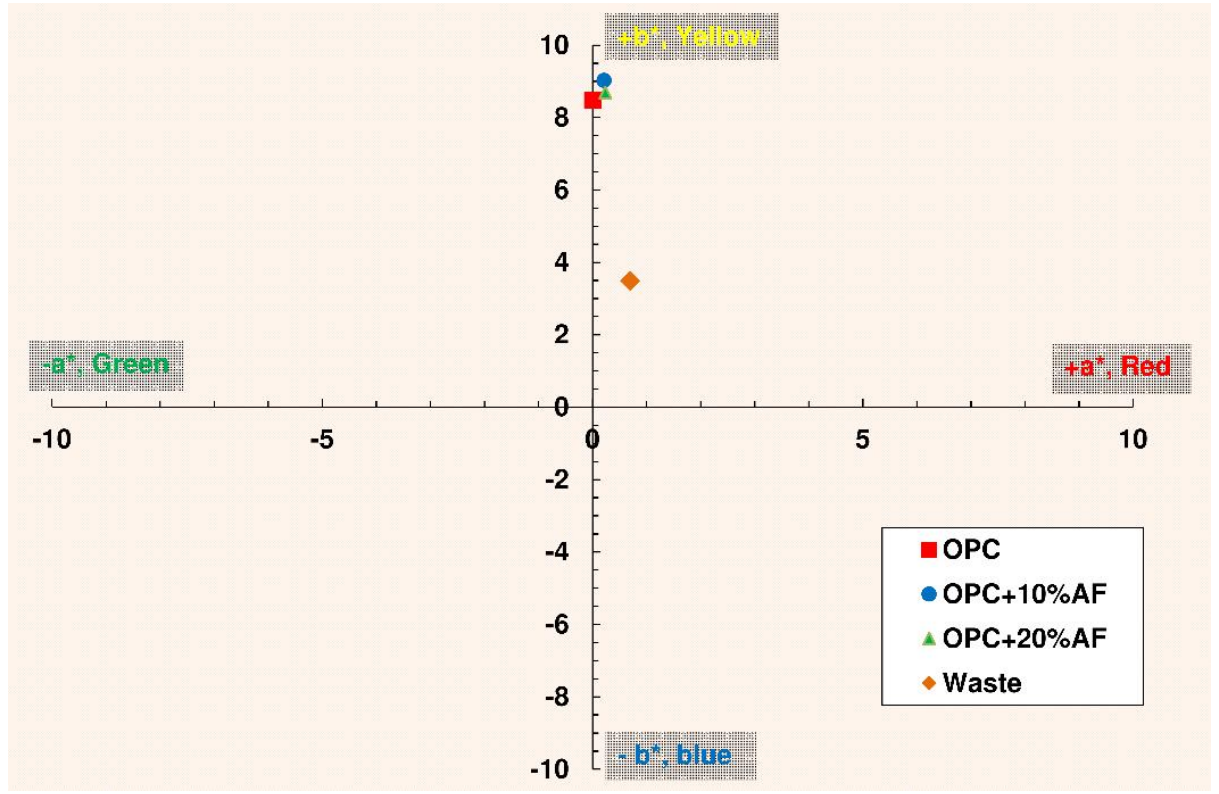

Figure 11. Colour coordinates $\left(a^{*}, b^{*}\right)$ for the anhydrous cements and granite quarry dust 